\title{
Hyperbaric oxygen therapy as additional treatment in deep sternal wound infections - a single center's experience
}

\author{
Radosław Litwinowicz¹, Magdalena Bryndza1, Anna Chrapusta², Ewa Kobielska², Bogusław Kapelak \\ Grzegorz Grudzień ${ }^{1}$
}

\author{
${ }^{1}$ Department of Cardiovascular Surgery and Transplantation, Institute of Cardiology, Jagiellonian University Medical College, \\ Krakow, Poland \\ ${ }^{2}$ Burns and Plastic Surgery, Centre of Malopolska, Ludwik Rydygier Memorial Hospital, Krakow, Poland
}

Kardiochirurgia i Torakochirurgia Polska 2016; 13 (3): 198-202

\begin{abstract}
Introduction: Deep sternal wound infection (DSWI) is one of the most serious complications after cardiac surgery procedures, observed in $5 \%$ of patients. Current standard medical therapy for DSWI includes antibiotics, surgical debridement, resuturing or negative pressure wound therapy (NPWT). Unfortunately, in some cases these methods are insufficient, and additional therapeutic options are needed.

Aim: To assess the effects and usefulness of additional hyperbaric oxygen therapy ( $\mathrm{HBO} 2)$ in patients with DSWI after cardiac surgery procedures.

Material and methods: A retrospective analysis of 10 patients after cardiac surgery who developed DSWI in the period 20102012 was performed. After 3 months of ineffective conventional therapy including targeted antibiotic, surgical sternal debridement and NPWT, patients were qualified for additional $\mathrm{HBO} 2$ therapy. A total of 20 sessions of $\mathrm{HBO} 2$ therapy were performed, each 92 minutes long.

Results: After 4 weeks of $\mathrm{HBO} 2$ treatment, 7 patients presented complete wound healing with fibrous scar formation. One patient was qualified for the another cycle of $\mathrm{HBO} 2$ therapy with 20 additional sessions, and complete wound healing was observed. In 2 cases, after 5 and 19 sessions, HBO2 was interrupted because of improper qualifications.

Conclusions: The $\mathrm{HBO} 2$ as an additional therapy in DSWI was successful in $80 \%$ of cases, and no complications were observed. However, due to the small number of published studies with a small number of patients, randomized, clinical trials are needed to assess the clinical results of $\mathrm{HBO} 2$ in DSWI after cardiac surgery procedures.

Key words: hyperbaric oxygen therapy, deep sternal wound infection.
\end{abstract}

\section{Streszczenie}

Wstęp: Pooperacyjne zapalenie śródpiersia (DSWI) będące najczęstszym powikłaniem kardiochirurgicznym występuje u ok. 5\% pacjentów. Obecnie standardowym leczeniem DSWI jest antybiotykoterapia celowana, chirurgiczne opracowanie rany, resutura mostka oraz terapia podciśnieniowa (NPWT). Niestety w niektórych przypadkach terapia ta jest niewystarczająca i wymaga uzupełnienia o inne metody.

Cel: Ocena zastosowania tlenoterapii hiperbarycznej (HBO2) w leczeniu DSWI u pacjentów po operacjach kardiochirurgicznych.

Materiał i metody: Retrospektywna analiza została przeprowadzona u 10 pacjentów z rozpoznanym DSWI operowanych w latach 2010-2012. Po 3 miesiącach nieefektywnego leczenia DSWI z wykorzystaniem antybiotykoterapii celowanej, chirurgicznego opracowania rany oraz NPWT pacjentów zakwalifikowano do leczenia HBO2 w modelu 20 sesji, każda po 92 minuty. Wyniki: Po 4 tygodniach $\mathrm{HBO} 2$ u 7 pacjentów nastąpiło całkowite zagojenie rany mostka. Jeden pacjent został skierowany na kolejny cykl zabiegów i także u niego nastąpiło zagojenie się rany. U dwóch pacjentów, po 5 i 19 sesjach, HBO2 została przerwana z powodu złej kwalifikacji do procedury.

Wnioski: Tlenoterapia hiperbaryczna okazała się skuteczna u 80\% pacjentów z rozpoznanym DSWI. Wydaje się skuteczną, tanią oraz bezpieczną metodą wspomagającą w leczeniu szczególnie trudnych, głębokich infekcji ran mostka. Ze względu na małą liczbę opisywanych przypadków otrzymane wyniki powinny stanowić wstęp do dalszych badań.

Słowa kluczowe: tlenoterapia hiperbaryczna, pooperacyjne zapalenia śródpiersia.

\footnotetext{
Address for correspondence: Radosław Litwinowicz MD, PhD, Department of Cardiovascular Surgery and Transplantation, Institute of Cardiology, Jagiellonian University Medical College, 80 Pradnicka St, 31-202 Krakow, Poland, phone: +48 1261430 75, fax: +48 126142525 ,

e-mail: litwa2@poczta.onet.pl.

Received: 11.06.2016, accepted: 13.09.2016.
} 


\section{Introduction}

Deep sternal wound infection (DSWI) is one of the most serious complications after cardiac surgery procedures. According to the literature, frequency of DSWI after cardiac surgery is from $0.5 \%$ to $5.3 \%$ with the early in hospital mortality range from $10 \%$ to $47 \%$ [1-4]. Deep sternal wound infection also increases the length of hospital stay, short- and long-term morbidity and medical costs [1, 4-7].

It is suggested that major mechanisms of DSWI are ischemia, hypoxia and nosocomial infections [7, 8]. Current standard medical therapy for DSWI includes antibiotics, surgical debridement, resuturing or negative pressure wound therapy (NPWT). Unfortunately, in some cases, these methods are insufficient and additional therapeutic options are needed.

In recent years hyperbaric oxygen therapy (HBO2) has become an approved treatment of patients with chronic, non-healing or difficult wounds. During $\mathrm{HBO} 2$ a short term of high pressure oxygen and atmospheric air is used to achieve hyperoxygenation of tissue. The dosage limits are determined by the toxicity of the $\mathrm{O}_{2}$ to the brain cells. The number of therapeutic sessions depends on the patient's clinical status and the type of treated disorder.

Hyperbaric oxygen therapy has a few different mechanisms improving wound healing, including anti-inflammatory effects, down-regulation of the cell adhesion molecules and diminished influence of leukocytes on the endothelium. Additionally, leukocyte killing capacity is enhanced, anaerobic bacteria are unable to grow, and production of clostridial $\alpha$ toxin is stopped. Hyperbaric oxygen therapy improves angiogenesis and vasculogenesis, and causes vasoconstriction and edema reduction. A wide range of growth factors and processes (e.g. cellular collagen synthesis) are stimulated by the availability of $\mathrm{O}_{2}$ in the cell matrix [9].

\section{Aim}

There are only a few papers about $\mathrm{HBO} 2$ therapy in patients with DSWI after a cardiac surgery procedure. The aim of this study was to present the effects and usefulness of $\mathrm{HBO} 2$ therapy in patients with deep sternal wound infections after a cardiac surgery operation.

\section{Material and methods}

In the period 2010-2012, ten patients who developed DSWI after cardiac surgery procedures were enrolled in the study. All data were collected retrospectively. Patients' characteristic are summarized in Table I.

Deep sternal wound infection was diagnosed according to the following criteria defined by the Centers for Disease Control and Prevention [10]: 1 - an organism isolated from culture of mediastinal tissue or fluid; 2 - evidence of mediastinitis seen during operation; or 3 - presence of chest pain, sternal instability, or fever $\left(>38^{\circ} \mathrm{C}\right)$, and either purulent drainage from the mediastinum, isolation of an organism present in a blood culture, or culture of the mediastinal area.
All patients were readmitted to hospital due to sternal dehiscence. Wound swabs were collected and empiric antibiotic therapy was indicated. In all cases culture reports and antibiotic susceptibility tests showed mixed multi-resistant bacterial or bacterial-fungal flora contaminations. Targeted antibiotic therapy was performed. The bacteriology data are presented in Table II.

Beside the targeted antibiotic, every patient underwent surgical sternal debridement and NPWT. The decision of additional HBO2 therapy was made after 3 months of ineffective conventional therapy.

Hyperbaric oxygen therapy was performed in a multiplace hyperbaric chamber at Lesser Poland Center of Hyperbaric Therapy, Rydygier Hospital in Cracow. Hyperbaric oxygen therapy sessions were performed daily from Monday to Friday with a break of 2 days. A total of 20 sessions were performed, each 92 minutes long.

\section{Results}

After 20 sessions of $\mathrm{HBO} 2$ therapy (4 weeks of treatment), 7 (70\%) patients presented complete wound healing with fibrous scar formation. One patient was qualified for another cycle of $\mathrm{HBO} 2$ therapy with 20 additional sessions, and after that complete wound healing with fibrous scar formation was observed.

In 2 cases, patients received 5 and 19 of 20 sessions; however, the $\mathrm{HBO} 2$ course was interrupted because of improper qualifications for $\mathrm{HBO} 2$ therapy. In both patients the sternum was completely destroyed by osteitis and the patients were qualified for sternal reconstructions with a musculocutaneous flap surgery procedure.

Tab. I. Patients' characteristics

\begin{tabular}{|c|c|}
\hline Parameter & Result \\
\hline Gender & $60 \%$ male : $40 \%$ female \\
\hline Age & Mean: 63 (range: 53-78) \\
\hline $\mathrm{BMI}\left[\mathrm{kg} / \mathrm{m}^{2}\right]$ & 30.3 (range: $24.8-33.5$ ) \\
\hline Procedure & $\begin{array}{l}\text { Isolated CABG - } 40 \% \\
\text { CABG + AVR - } 20 \% \\
\text { CABG + MV repair - 20\% } \\
\text { CABG + MVR - } 10 \% \\
\text { Debranching - } 10 \%\end{array}$ \\
\hline Hypertension & $80 \%$ \\
\hline Diabetes mellitus & $50 \%$ \\
\hline Hyperlipidemia & $50 \%$ \\
\hline Atrial fibrillation & $20 \%$ \\
\hline Renal failure & $10 \%$ \\
\hline COPD & $10 \%$ \\
\hline Peripheral vessel disease & $10 \%$ \\
\hline Hepatitis C & $10 \%$ \\
\hline EuroSCORE II & 5.86 (range: 2-15.8) \\
\hline STS SCORE & $2.167 \%$ (range: $0.4-3.4$ ) \\
\hline STS infection PREOPERATIVE risk score & $7.6 \%$ (range: $1.9-11.4$ ) \\
\hline STS infection COMBINED risk score & $5.76 \%$ (range: $1.3-10.7$ ) \\
\hline
\end{tabular}


Tab. II. Microorganisms isolated from the patients' wound swabs

\begin{tabular}{ll} 
Pathogen & $\begin{array}{l}\text { Percent of infected } \\
\text { patients }\end{array}$ \\
Staphylococcus epidermidis MRS & 80 \\
\hline Klebsiella pneumoniae ESBL & 20 \\
\hline Enterobacter cloacae ESBL & 20 \\
\hline Staphylococcus aureus MSSA & 20 \\
\hline Staphylococcus haemolyticus MRS & 20 \\
\hline Staphylococcus hominis MRS & 20 \\
\hline Streptococcus agalactiae & 10 \\
\hline Klebsiella ornithinolytica ESBL & 10 \\
\hline Serratia marcescens & 10 \\
\hline Pseudomonas aeruginosa & 10 \\
\hline Enterococcus faecium & 10 \\
\hline Acinetobacter baumannii & 10 \\
\hline Acinetobacter haemolyticus & 10 \\
\hline Clostridium difficile & 10 \\
\hline Corynebacterium jeikeium & 10 \\
\hline Corynebacterium amycolatum & 10 \\
\hline Pediococcus pentosaceus & 10 \\
\hline Bacillus spp. & 10 \\
\hline Candida albicans & 10 \\
\hline Candida parapsilosis & 10 \\
\hline Staphylococcus aureus MRS & 10 \\
\hline Staphylococcus epidermidis MSS & 10 \\
\hline
\end{tabular}

During $\mathrm{HBO} 2$ therapy no complications were observed. Figures 1 and 2 present wounds before and after $\mathrm{HBO} 2$ therapy.

\section{Discussion}

The incidence of postoperative DSWJ after cardiac surgery is rather low and ranges from $0.5 \%$ to $5.3 \%[1-4,11$, 12]. However, DSWI is one of the most serious complica-

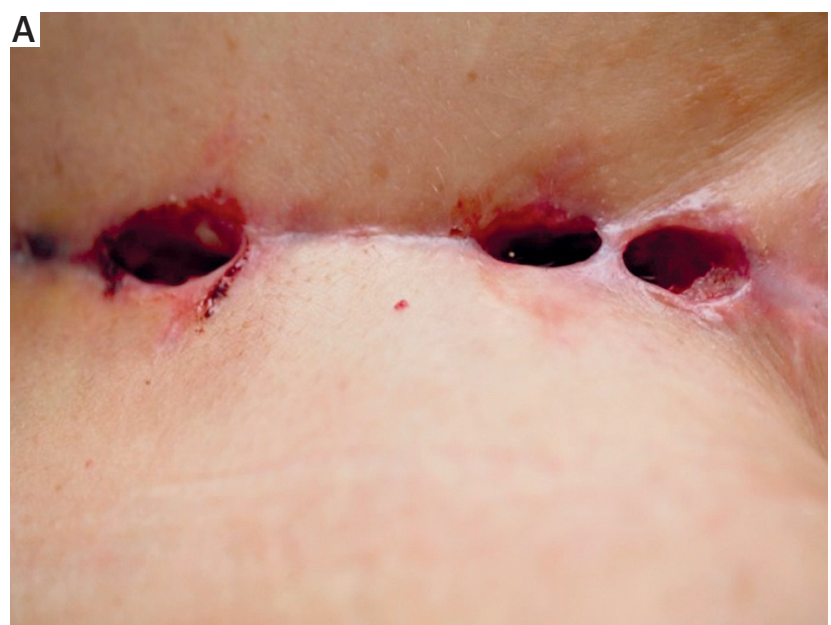

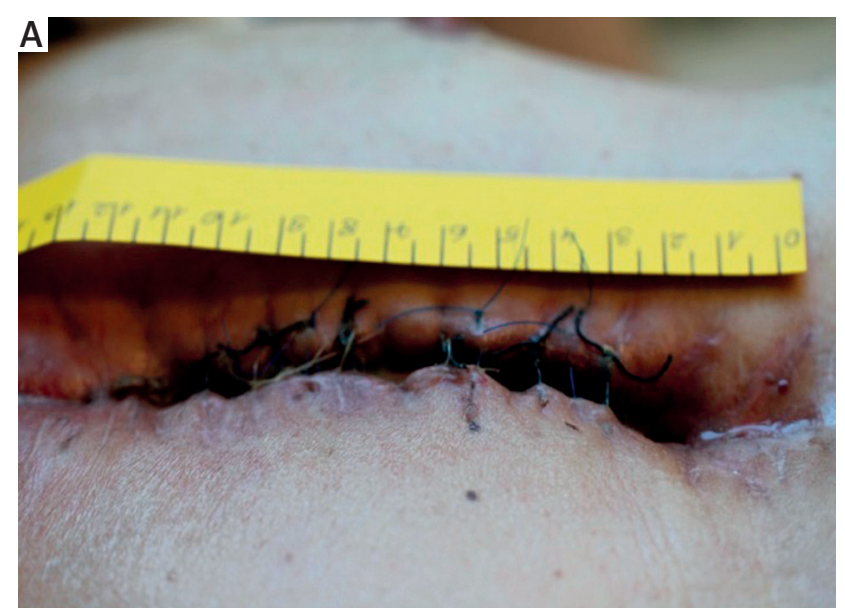

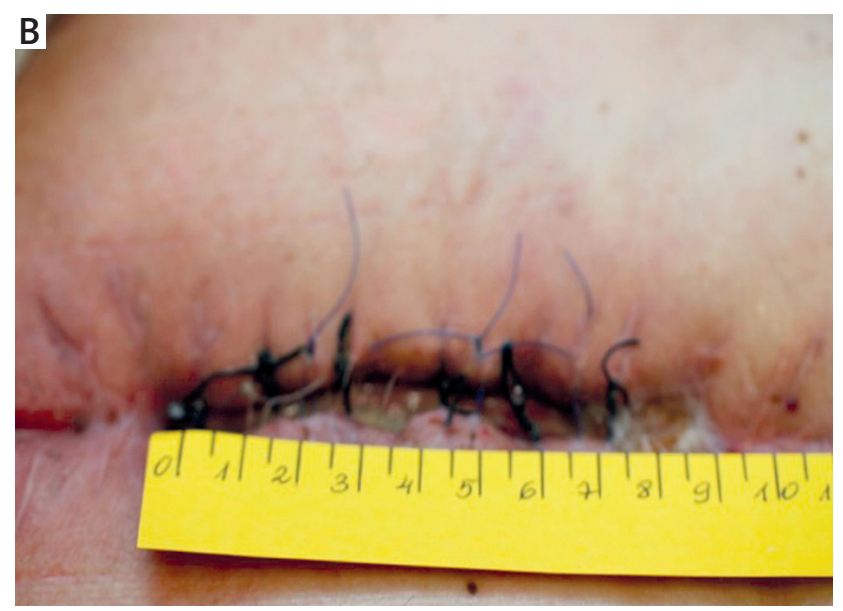

Fig. 1. A - Male patient before $\mathrm{HBO} 2$ therapy, B - the same male patient after $\mathrm{HBO} 2$ therapy

tions, significantly increasing postoperative mortality, morbidity, time of hospitalization, hospital costs and need for surgical re-intervention [13]. According to the literature, many factors have been found as DSWI risk factors and only some of them are modifiable [14-16]. Moreover, nowadays cardiac surgery patients mostly have at least two risk

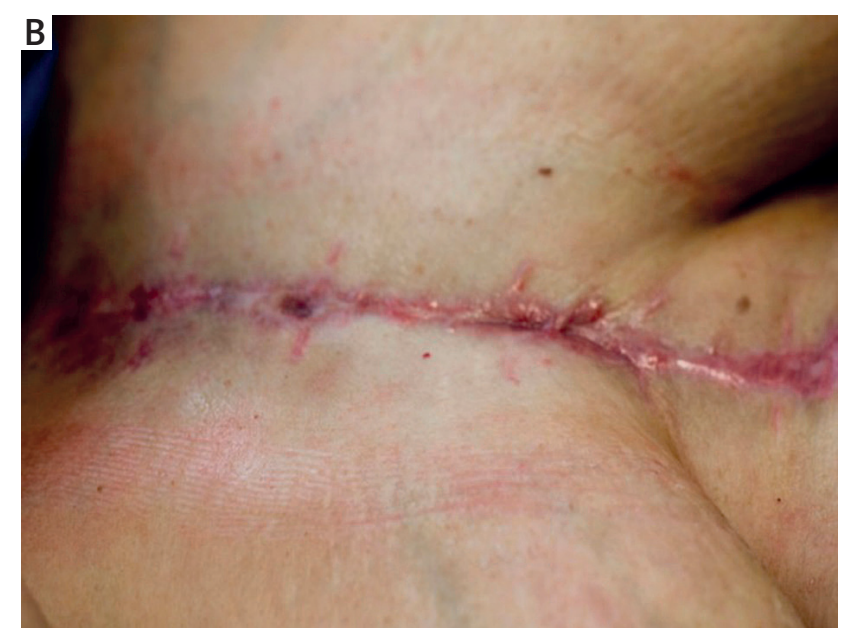

Fig. 2. A - Female patient before $\mathrm{HBO} 2$ therapy, $\mathrm{B}$ - the same female patient after $\mathrm{HBO} 2$ therapy 
factors for postoperative DSWI because of their older age and comorbidities [17].

Currently, debridement, directed antibiotics and NPWT are standard treatments in DSWI. Importantly, additional therapy algorithms may vary among surgeons. Past treatment options have included closed suction and continuous irrigation. Current paradigms in the management of sternal wound infection include surgical debridement, vacuumassisted closure therapy, flap coverage, and sternal plating [18]. Unfortunately, in the available literature there is still insufficient information about hyperbaric oxygen therapy as an alternative treatment option in DSWI [1, 2].

Hyperbaric oxygen therapy is widely used in surgery, with benefits observed in wound healing and limb salvage such as traumatic brain injury, chronic wounds, diabetic wounds, arterial ulcers, stasis ulcers, limb amputations, calciphylaxis, intractable vasculitic ulcers and others [19]. Hyperbaric oxygen therapy is defined as compression of the whole body with at least 1.4 atmospheres absolute pressure of pure oxygen [20]. Oxygen pressure increases and promotes collagen matrix formation, angiogenesis, cytoprotection, osteoclast/osteoblast activity and bone union, improves the effect of neutrophil response and increases the synergistic effect of antibiotics [21-24].

It has been shown that sternal ischemia and hypoxia may play a main role in indication of DSWI [2, 8, 9]. For that reason the mechanism of $\mathrm{HBO} 2$ therapy may bring potential healing benefits. In our study, $\mathrm{HBO} 2$ therapy as an additional treatment in DSWI was successful in $80 \%$ of cases. Two cases were unsuccessful (20\%) because of the completely destroyed sternum and wrong qualification for HBO2 therapy.

In our study, the decision of $\mathrm{HBO} 2$ therapy was based on the physician's personal clinical decision after 3 months of ineffective treatment. The extended 3-month period in our department was due to the qualifying period of ineffective treatment that must elapse to receive reimbursement for $\mathrm{HBO} 2$ treatment. However, it should be emphasized that in the author's opinion $\mathrm{HBO} 2$ therapy should be started when there is the first clinical evidence that standard methods of treatment in DSWI are insufficient.

In the literature, the timing of $\mathrm{HBO} 2$ therapy varied depending on the performed study. Barili et al. started $\mathrm{HBO} 2$ therapy after diagnosis of DSWI [25]; Yu et al. started HBO2 2 weeks to months after DSWI diagnosis [2], Higuchi et al. reported the initiation of $\mathrm{HBO} 2$ therapy for patients with persistent osteomyelitis after standard treatment [26]. However, the timing of $\mathrm{HBO} 2$ therapy for DSWI has been discussed, and all performed studies, including our results, present very good clinical results.

It should be mentioned that in all patients the conventional LIMA harvesting was done by opening the cadaver's chest with a mid-sternotomy incision in the CABG procedure. Studies and investigational experiments showed that the internal mammary artery (IMA) is one of the most important risk factors of DSWI because of the IMA's role in the blood supply of the sternum [8].
Currently, there are no guidelines or official clinical indications of $\mathrm{HBO} 2$ therapy in DSWI. There are only a few cases reports $[2,25,26]$ and no randomized controlled trials [1, 27, 28] to support or reject the use of $\mathrm{HBO} 2$ in DSWI. Most of the published articles present level $\mathrm{V}$ evidence, which provides weak evidence to support the use of $\mathrm{HBO} 2$ in treatment, although the obtained results are encouraging [7]. What is also important, one of the main limitations of $\mathrm{HBO} 2$ therapy is the distance between hyperbaric units and the cardiac surgery center. In our center we started to perform HBO2 therapy as additional treatment in DSWI shortly after the hyperbaric units were established in our town.

In our opinion, the potential benefits of $\mathrm{HBO} 2$ therapy as an additional treatment in DSWI are that it is a noninvasive, non-burdensome and safe procedure. However, to confirm or refute the benefits of $\mathrm{HBO} 2$ therapy further, a blinded randomized controlled trial on a large group of patients is needed.

Our study had several limitations. First, the number of cases was small. Second, there was no control group. Third, we performed a retrospective study; therefore some data may be missing or poorly documented. Fourth, the authors focused only on the clinical outcomes of studied patients.

\section{Conclusions}

In this retrospective study, performed on a small group of patients, $\mathrm{HBO} 2$ as an additional therapy in deep sternal wound infections was successful in $80 \%$ of cases. It improves sternum stabilization, wound sterilization and final healing. No complications of $\mathrm{HBO} 2$ therapy were observed. $\mathrm{HBO} 2$ is an alternative way of treatment but definitely worth considering, especially in patients in whom standard pharmacotherapy and NPWT have failed. However, due to the small number of published studies on a very small number of patients, randomized, clinical trials are needed to assess the clinical results of $\mathrm{HBO} 2$ in DSWI after cardiac surgery procedures.

\section{Disclosure}

Authors report no conflict of interest.

\section{References}

1. Egito JG, Abboud CS, Oliveira AP, Máximo CA, Montenegro CM, Amato VL, Bammann R, Farsky PS. Clinical evolution of mediastinitis in patients undergoing adjuvant hyperbaric oxygen therapy after coronary artery bypass surgery. Einstein (Sao Paulo) 2013; 11: 345-349.

2. Yu WK, Chen YW, Shie HG, Lien TC, Kao HK, Wang JH. Hyperbaric oxygen therapy as an adjunctive treatment for sternal infection and osteomyelitis after sternotomy and cardiothoracic surgery. J Cardiothorac Surg 2011; 6: 141-146.

3. Braxton JH, Marrin CA, McGrath PD, Ross CS, Morton JR, Norotsky M, Charles worth DC, Lahey SJ, Clough RA, O'Connor GT; Northern New England Cardiovascular Disease Study Group. Mediastinitis and long-term survival after coronary artery bypass graft surgery. Ann Thorac Surg 2000; 70: 2004-2007.

4. Milano CA, Kesler K, Archibald N, Sexton DJ, Jones RH. Mediastinitis after coronary artery bypass graft surgery. Risk factors and long-term survival. Circulation 1995; 92: 2245-2251.

5. Kappstein I, Schulgen G, Fraedrich G, Schlosser V, Schumacher M, Daschner FD. Added hospital stay due to wound infections following cardiac surgery. Thorac Cardiovasc Surg 1992; 40: 148-151. 
6. Litwinowicz R, Bartus K, Drwila R, Kapelak B, Konstanty-Kalandyk J, Sobczynski R, Wierzbicki K, Bartuś M, Chrapusta A, Timek T, Bartus S, Oles K, Sadowski J. In-hospital mortality in cardiac surgery patients after readmission to the intensive care unit: a single-center experience with 10,992 patients. J Cardiothorac Vasc Anesth 2015; 29: 570-575.

7. Mills C, Bryson P. The role of hyperbaric oxygen therapy in the treatment of sternal wound infection. Eur J Cardiothorac Surg 2006; 30: 153-159.

8. Francel TJ, Dufresne CR, Baumgartner WA, O'Kelley J. Anatomic and clinical considerations of an internal mammary artery harvest. Arch Surg 1992; 127: 1107-1111.

9. Mathieu D (ed.). Handbook on hyperbaric medicine. Vol. 27. Springer, New York 2006.

10. Garner JS, Jarvis WR, Emori TG, Horan TC, Hughes JM. CDC definitions for nosocomial infections, 1988. Am J Infect Control 1988; 16: 128-140.

11. Loop FD, Lytle BW, Cosgrove DM, Mahfood S, McHenry MC, Goormastic M, Stewart RW, Golding LA, Taylor PC. J. Maxwell Chamberlain memorial paper. Sternal wound complications after isolated coronary artery bypass grafting: early and late mortality, morbidity, and cost of care. Ann Thorac Surg 1990; 49: 179-186; discussion 186-187.

12. Toumpoulis IK, Anagnostopoulos CE, Derose JJ Jr, Swistel DG. The impact of deep sternal wound infection on long-term survival after coronary artery bypass grafting. Chest 2005; 127: 464-471.

13. Abboud CS, Wey SB, Baltar VT. Risk factors for mediastinitis after cardiac surgery. Ann Thorac Surg 2004; 77: 676-683.

14. Farsky PS, Graner H, Duccini P, Zandonadi Eda C, Amato VL, Anger J, Sanches AF, Abboud CS. Risk factors for sternal wound infections and application of the STS score in coronary artery bypass graft surgery. Rev Brasil Cir Cardiovasc 2011; 26: 624-629.

15. Okonta KE, Anbarasu M, Agarwal V, Jamesraj J, Kurian VM, Rajan S. Sternal wound infection following open heart surgery: appraisal of incidence, risk factors, changing bacteriologic pattern and treatment outcome. Indian J Thorac Cardiovasc Surg 2011; 27: 28-32.

16. Culliford AT, Cunningham JN Jr, Zeff RH, Isom OW, Teiko P, Spencer FC. Sternal and costochondral infections following open-heart surgery. A review of 2,594 cases. J Thorac Cardiovasc Surg 1976; 72: 714-726.
17. De Feo M, Gregorio R, Della Corte A, Marra C, Amarelli C, Renzulli A, Utili R, Cotrufo $M$. Deep sternal wound infection: the role of early debridement surgery. Eur J Cardiothorac Surg 2001; 19: 811-816.

18. Singh K, Anderson E, Harper JG. Overview and management of sternal wound infection. Semin Plast Surg 2011; 25: 25-33.

19. Goldman RJ. Hyperbaric oxygen therapy for wound healing and limb salvage: a systematic review. PM R 2009; 1: 471-489.

20. Feldmeier JJ. Hyperbaric oxygen 2003: indications and results: the hyperbaric oxygen therapy committee report. Undersea and Hyperbaric Medical Society 2003.

21. Sawai T, Niimi A, Takahashi H, Ueda M. Histologic study of the effect of hyperbaric oxygen therapy on autogenous free bone grafts. J Oral Maxillofac Surg 1996; 54: 975-981.

22. Godman CA, Chheda KP, Hightower LE, Perdrizet G, Shin DG, Giardina C. Hyperbaric oxygen induces a cytoprotective and angiogenic response in human microvascular endothelial cells. Cell Stress Chaperones 2010; 15: 431-442.

23. Hopf HW, Gibson JJ, Angeles AP, Constant JS, Feng JJ, Rollins MD, Zamirul Hussain M, Hunt TK. Hyperoxia and angiogenesis. Wound Repair Regen 2005; 13: 558-564.

24. Cimsit M, Uzun G, Yildiz S. Hyperbaric oxygen therapy as an anti-infective agent. Expert Rev Anti Infect Ther 2009; 7: 1015-1026.

25. Barili F, Polvani G, Topkara VK, Dainese L, Cheema FH, Roberto M, Naliato M, Parolari A, Alamanni F, Biglioli P. Role of hyperbaric oxygen therapy in the treatment of postoperative organ/space sternal surgical site infections. World J Surg 2007; 31: 1702-1706.

26. Higuchi T, Oto T, Millar IL, Levvey BJ, Williams TJ, Snell GI. Preliminary report of the safety and efficacy of hyperbaric oxygen therapy for specific complications of lung transplantation. J Heart Lung Transplant 2006; 25: 1302-1309.

27. Siondalski P, Keita L, Sicko Z, Zelechowski P, Jaworski L, Rogowski J. Surgical treatment and adjunct hyperbaric therapy to improve healing of wound infection complications after sterno-mediastinitis. Pneumonol Alergol Pol 2002; 71: 12-16.

28. Petzold T, Feindt PR, Carl UM, Gams E. Hyperbaric oxygen therapy in deep sternal wound infection after heart transplantation. Chest J 1999; 115: 1455-1458. 